\title{
Processing of ultrafine-grained materials using severe plastic deformation: potential for achieving exceptional properties ${ }^{(*)}$
}

\author{
T.G. Langdon ${ }^{* * *}$
}

\begin{abstract}
The processing of polycrystalline metals through the application of severe plastic deformation is attracting much attention because of the potential for achieving significant grain refinement to the submicrometer or nanometer level. This paper reviews the principles of this type of processing with emphasis on two different techniques: EqualChannel Angular Pressing and High-Pressure Torsion. Exceptional properties may be achieved from these processes including high strength at ambient temperatures and a rapid superplastic forming capability at elevated temperatures. Some examples are presented demonstrating the potential use of this type of processing.
\end{abstract}

\section{Proceso de materiales ultrafino-granulosos usando la deformación plástica severa: potencial para alcanzar características excepcionales}

Resumen

Palabras clave

\begin{abstract}
El procesado de metales policristalinos a través de deformación plástica severa está atrayendo mucha atención, debido al potencial para alcanzar un importante afino de grano a niveles submicrométricos o nanométricos. Esta publicación revisa los principios de este tipo de procesado haciendo hincapié en dos técnicas diferentes: prensado en canal angular y torsión bajo alta presión. Mediante estos procesos, se pueden alcanzar propiedades excepcionales incluyendo alta resistencia a temperatura ambiente y una capacidad de conformación superplástica rápida a elevadas temperaturas. Se presentan algunos ejemplos demostrando el uso potencial de este tipo de procesado.
\end{abstract}

Prensado en canal angular; torsión bajo alta presión; deformación plástica severa; granos ultrafinos.

\section{PREAMBLE}

It is a pleasure and an honor for me to have this opportunity to present a Plenary Lecture and to prepare this report marking the 60th anniversary of metallurgical research in CSIC. The quality and the breadth of the metallurgical research activities at CENIM are now well known around the world. On a personal note, I have followed for many years the research activities of Dr. Óscar Ruano of CENIM in the field of high temperature creep. It is appropriate, therefore, to look back and examine the situation in 1948 at the time when metallurgical research was first established at the institute in Madrid.
The year of 1948 followed shortly after World War II when the countries of Europe were beginning to recommence their research activities. Looking through the scientific literature for 1948, there are several classic papers, all published by the leaders in our field, relevant to high temperature flow and deformation. Examples from England include Professor E.N.daC. Andrade on "Creep of Metals and Recrystallization" [1], Professor N.F. Mott on "Slip of Grain Boundaries and Grain Growth in Metals" [2] and Professor E. Orowan on "X-ray Line Broadening in Cold-Worked Metals" [3], from Australia Professor W.A. Rachinger published "Strength of Metals" [4] and from the United States Dr. T.S. Kê published "On the Structure of Grain Boundaries in Metals"

(•) Submitted to Revista de Metalurgia: Plenary Lecture for 60th Anniversary of Metallurgical Research at CSIC (September 2008)

* Departments of Aerospace \& Mechanical Engineering and Materials Science, University of Southern California, Los Angeles, CA 900891453, U.S.A.

** Materials Research Group, School of Engineering Sciences, University of Southampton, Southampton SO17 1BJ, U.K., e-mail langdon@usc.edu. 
[5]. At least some of these papers will be familiar to many of the materials scientists working in research at the present time and indeed it is readily apparent from their titles that all of these publications are relevant, and have close similarities, to our work today, sixty years later, in modern Materials Science.

And yet, despite the importance of these contributions, there remains one additional paper, also published in 1948, which has had an even greater impact on the field of modern metallurgical research. In July 1947 a conference on "Strength of Solids" was held at the University of Bristol in England. When the proceedings were published in 1948 they contained a seminal paper by F.R.N. Nabarro who was then a Royal Society Warren Research Fellow in Bristol. This paper, entitled "Deformation of Crystals by the Motion of Single Ions" [6], set out the basic concept of diffusion creep whereby plastic flow occurs by the stress-directed diffusion of vacancies through the grains of a polycrystalline matrix. This concept, when combined with the subsequent theoretical analysis of Herring in $1950^{[7]}$, established the basic principles of the mechanism of NabarroHerring diffusion creep and it is significant to note that this flow process has played, and continues to play, a considerable role in our interpretations of the creep of polycrystalline metals at very low stresses. Accordingly, it is appropriate to record that the establishment of metallurgical research at CSIC sixty years ago in 1948 occurred in the same year that the basic concept of diffusion creep was first introduced as a potential flow mechanism in the field of high temperature deformation.

\section{INTRODUCTION TO SEVERE PLASTIC DEFORMATION}

The processing of metals through the application of severe plastic deformation (SPD) refers to the various experimental procedures in which high strains are imposed on metal samples using special tool geometries so that free flow is prevented and the processing operation occurs under a hydrostatic pressure ${ }^{[8]}$. A critical requirement in SPD processing is that the material experiences a very high strain without introducing any significant changes in the overall dimensions of the workpiece. This means that SPD processing differs in a critical way from more conventional industrial processes such as extrusion, rolling and drawing. Although the history of this type of processing may be traced back more than 2000 years to the metal-working practices of ancient China ${ }^{[0]}$, it is only within the last few decades that sophisticated analytical tools have become available demonstrating that the imposition of these very high strains leads to significant grain refinement and to the production of arrays of ultrafine grains having average sizes in the submicrometer or even the nanometer range.

Processing by SPD is now an accepted procedure for the fabrication of bulk solids having exceptionally small grain sizes where these grains are smaller than those that can be attained using conventional thermo-mechanical processing ${ }^{[10]}$. Although there are several different SPD processing procedures, most attention is currently directed to the two processes of Equal-Channel Angular Pressing (ECAP) ${ }^{[11]}$ and High-Pressure Torsion (HPT) ${ }^{[12]}$.

The principles of ECAP are depicted schematically in figure $1^{[13]}$. The sample, in the form of a rod or bar, is machined to fit within a channel contained in an ECAP die and it is then pressed through the die using a plunger. The channel is bent through an abrupt angle within the die, often an angle close to or equal to $90^{\circ}$, so that the sample experiences shearing as it passes through the die but ultimately it emerge having experienced no change in the crosssectional dimensions. In figure 1 the letters $X, Y$ and $Z$ denote three orthogonal planes where $X$ is the transverse plane, $Y$ is the flow plane and $Z$ is the longitudinal plane. It can be shown from simple geometric calculations that the strain imposed on the sample in a single pass depends primarily upon the angle between the two parts of the channel but also to a minor extent upon the magnitude of the

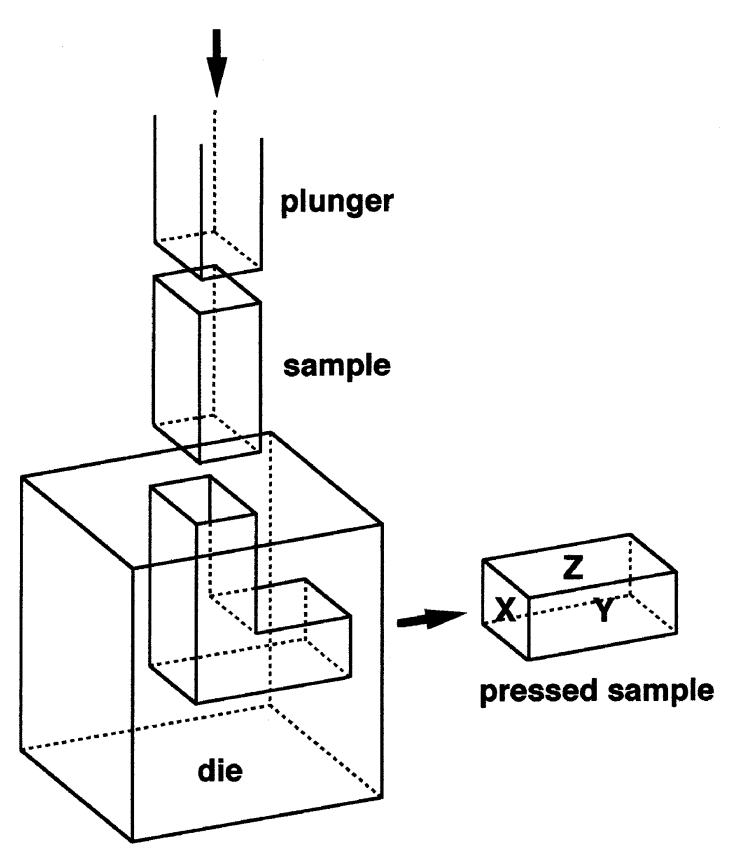

Figure 1. The principles of ECAP[13].

Figura 1. Los principios de ECAP[13]. 
angle representing the outer arc of curvature where the two parts of the channel intersect: this latter angle is equal to $0^{\circ}$ in figure 1 . Nevertheless, it is reasonable to assume to a first approximation that the strain is essentially $\sim 1$ when the angle between the two parts of the channel is $90^{\circ}$ [14].

Since the sample emerges from the die without any changes in the cross-sectional dimensions, repetitive pressings may be conducted in order to impose very high strains. These repetitive pressings also provide an opportunity for initiating new slip systems by rotating the sample about the longitudinal axis between consecutive passes. Four different processing routes have been developed for use in ECAP, where route $\mathrm{A}$ refers to processing without any rotation of the sample, route $B_{A}$ refers to a rotation of the sample through $90^{\circ}$ in alternate directions between each pass, route $B_{C}$ refers to a rotation through $90^{\circ}$ in the same direction between each pass and route $\mathrm{C}$ refers to a rotation through $180^{\circ}$ between passes ${ }^{[15}$ and 16$]$. It has been shown experimentally that, when using an ECAP die with an angle of $90^{\circ}$ between the two parts of the channel, optimum processing is achieved using route $\mathrm{B}_{\mathrm{C}}$ because this leads most rapidly both to an array of reasonably equiaxed grains and to a high fraction of grain boundaries having high angles of misorientation ${ }^{[17]}$.

The principle of HPT is illustrated in figure 2 where two massive anvils are placed in vertical alignment and with each anvil having a small depression machined on the inner surface ${ }^{[18]}$. These depressions are spherical in shape with typical

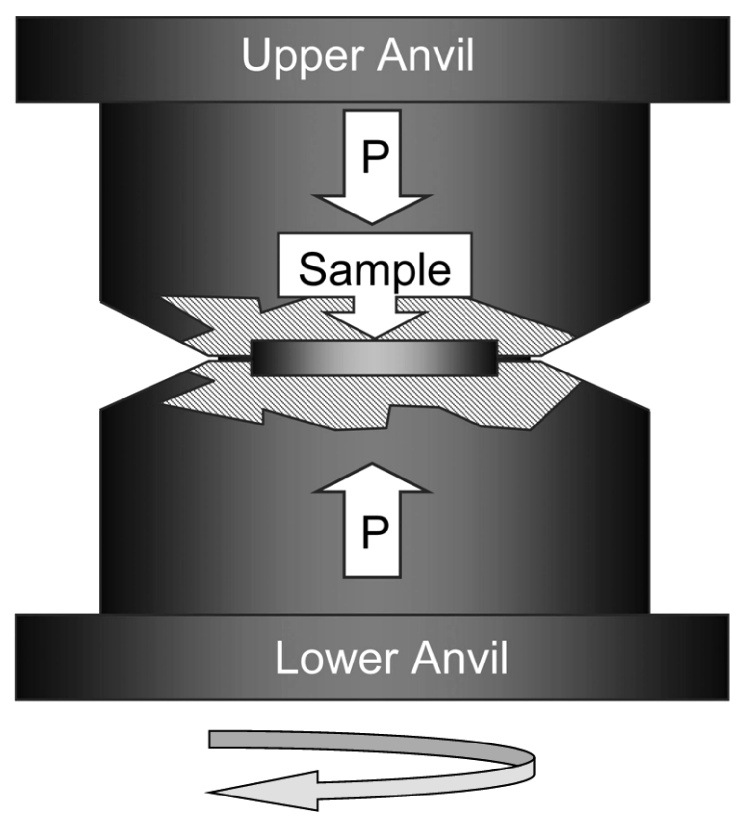

Figure 2. The principles of HPT[18].

Figura 2. Los principios de HPT ${ }^{[18]}$. diameters of $10 \mathrm{~mm}$ and depths of $0.25 \mathrm{~mm}$. The test sample is usually in the form of a disk with a thickness of $\sim 0.8 \mathrm{~mm}$. This disk is carefully placed in the depression on the lower anvil and the anvil is then raised so that the sample fits into the similar depression on the lower surface of the upper anvil. Processing by HPT involves two steps. First, the application of an applied pressure, $P$, which leads to some limited outward flow of the sample around the periphery of the disk as illustrated in figure 2 . Second, the disk is subjected to torsional straining through a rotation of the lower anvil through a selected number of rotations.

There are two important differences between ECAP and HPT. First, processing by ECAP involves the use of bulk solids and in practice the procedure may be easily scaled-up for use with relatively large billets ${ }^{[19}$ and 20]. By contrast, the samples used in HPT are generally in the form of thin disks although recent experiments demonstrated the feasibility of using HPT with bulk cylindrical samples ${ }^{[21}$ and 22]. Second, processing by ECAP is a discontinuous procedure so that it is easy to incorporate rotations of the samples between each consecutive pass through the die. By contrast, HPT processing is a continuous procedure and it is not necessary to remove the sample during the processing operation. This means it is not feasible to develop processing routes as in ECAP but, nevertheless, tests may be conducted where the samples are subjected to regular strain reversals in which the direction of torsional straining is reversed ${ }^{[23]}$.

\section{EXAMPLES OF PROPERTIES ATTAINED THROUGH PROCESSING BY ECAP}

The important characteristic of SPD processing is that it leads to exceptional grain refinement that cannot be achieved using conventional thermomechanical processing. An example is shown in figure 3 for (a) an Al-1\% Mg alloy processed by ECAP through 6 passes to give a grain size of $\sim 0.45 \mu \mathrm{m}$ and (b) an $\mathrm{Al}-3 \% \mathrm{Mg}$ alloy processed by ECAP through 8 passes to give a grain size of $\sim 0.27 \mu \mathrm{m}{ }^{[24]}$. This remarkable grain refinement was achieved by conducting the ECAP at room temperature using a pressing speed of $\sim 19 \mathrm{~mm} \mathrm{~s}^{-1}$ and an ECAP die with an internal channel angle of $90^{\circ}$. For both alloys, the grain sizes were $\sim 500 \mu \mathrm{m}$ in the unpressed condition. Also shown in figure 3 are the selected area electron diffraction patterns which confirm the presence of arrays of grain boundaries having high angles of misorientation. The principles of grain refinement have been determined by conducting ECAP 


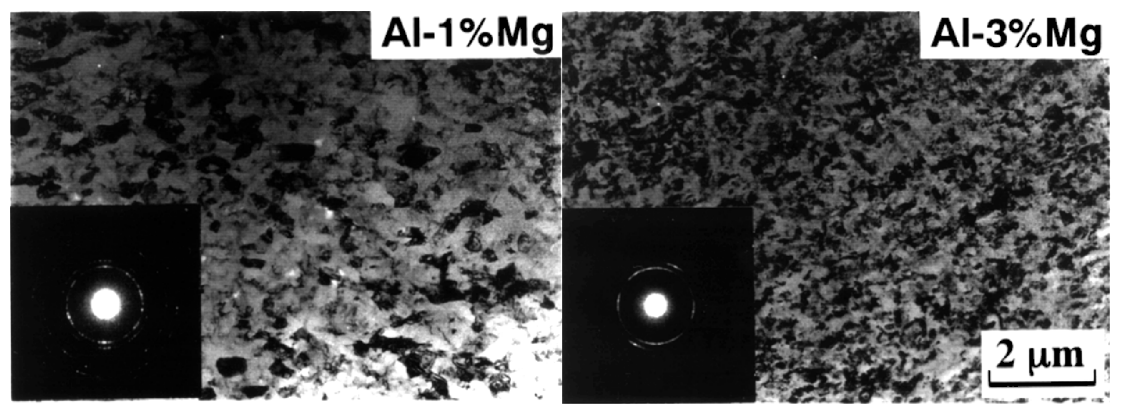

Figure 3. Ultrafine submicrometer grains produced by ECAP processing in (a) Al-1\% $\mathrm{Mg}$ and (b) Al$3 \% \mathrm{Mg}^{[24]}$.

Figura 3. Granos ultrafinos submicrométricos producidos por procesado por ECAP en a) Al-1\% Mg $y$ (b) $\mathrm{Al}-3 \% \mathrm{Mg}^{[24]}$.

processing on single crystals having different crystallographic orientations with respect to the loading axis and then comparing these results with polycrystalline data ${ }^{[25]}$.

It is well known that the strength of a polycrystalline material is related to the grain size, $d$, through the Hall-Petch relationship which states that the yield stress, $\sigma_{y}$, is given by

$$
\sigma_{y}=\sigma_{0}+k_{y} d^{+1 / 2}
$$

Where, $\sigma_{o}$ is termed the friction stress and $k_{y}$ is a constant of yielding [26 and 27]. It is immediately apparent from eq. (1) that a reduction in grain size should lead to a significant increase in the strength of the material. An example of this effect is shown in figure 4 which plots the $0.2 \%$ proof stress against the equivalent strain for a series of commercial aluminum alloys ranging from $\mathrm{Al}-1100$ to $\mathrm{Al}-7075$ [28]: since the ECAP was conducted using a die with a channel angle of $90^{\circ}$, an equivalent strain of 1 corresponds to a single pass through the die. For all of the alloys shown in figure 4 , it is apparent there is a very significant strengthening in the first pass and thereafter there is only a minor additional strengthening in subsequent passes. Similar results were reported also for the ultimate tensile stress in each alloy ${ }^{[28]}$.

If the ultrafine grains introduced by SPD processing are fairly stable at elevated temperatures, it is reasonable to anticipate these materials will exhibit excellent superplastic ductilities when testing in tension. Furthermore, since the strain rate in superplastic flow varies inversely with the grain size raised to a power of $2^{[29]}$, it was suggested in early studies of SPD processing that it should be possible to achieve superplasticity at exceptionally high strain rates in these materials ${ }^{[30]}$. The occurrence of high strain rate superplasticity was first demonstrated for

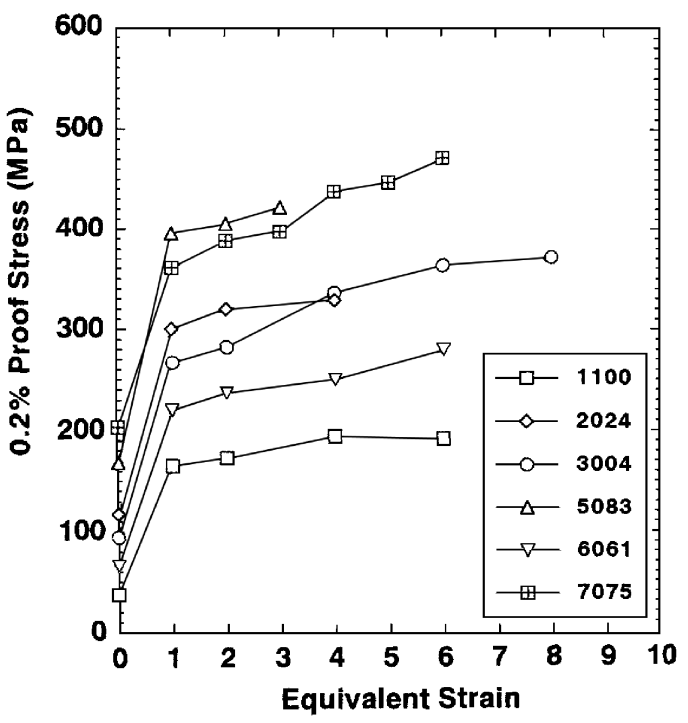

Figure 4. The $0.2 \%$ proof stress as a function of the equivalent strain produced in ECAP for six different commercial aluminum-based alloys ${ }^{[28]}$.

Figura 4. La tensión a 0.2\% en función de la deformación equivalente producida en ECAP para seis diferentes aleaciones comerciales de base aluminio[28].

two commercial aluminum alloys processed by ECAP where tensile elongations were recorded of up to $>1000 \%$ at a testing strain rate of $1.0^{\prime} 10^{-2} \mathrm{~s}^{-1[31]}$.

A detailed example of this effect is shown in figure 5 where results are presented for a commercial Al5.5\% Mg-2.2\% Li-0.12\% $\mathrm{Zr}$ alloy with the elongations recorded after pressing using route $B_{C}$ through (a) 4 passes at $673 \mathrm{~K}$ and (b) 8 passes at $673 \mathrm{~K}$ and an additional 4 passes at $473 \mathrm{~K}$ : the solid points at the lower levels in figure 5 denote the results obtained from samples in the unpressed condition with a grain size of 
$\sim 400 \mu \mathrm{m}{ }^{[32]}$. It is apparent from figure. 5 a) that SPD processing leads to the occurrence of exceptionally high superplastic elongations which are not attained in the unpressed alloy and, in addition, these high elongations occur at very rapid strain rates. Furthermore, if the alloy is pressed through a total of 12 passes, as shown in figure $5 \mathrm{~b})$, these very high elongations are displaced to even faster strain rates with elongations $>1000 \%$ at strain rates of $\sim 10^{-1} \mathrm{~s}^{-1}$.

Superplastic forming is now a major industry for the fabrication of complex parts for use in aerospace, automotive and other applications ${ }^{[33]}$. However, an inherent problem in using forming operations with conventional superplastic alloys is that the optimum strain rates generally occur in the vicinity of $\sim 10^{-3}$ to $10^{-2} \mathrm{~s}^{-1}$ so that the forming times are typically of the order of 20-30 minutes for each separate component. The use of SPD processing provides an opportunity for conducting forming operations at faster strain rates, thereby providing the potential for extending the use of this technology into new areas such as in the fabrication of large-volume consumer products. To check the feasibility of this approach, disks were cut from a billet of an Al-3\% Mg-0.2\% Sc alloy after processing by ECAP and these disks were inserted into a biaxial gas-pressure forming facility and then subjected to a gas pressure of 10 atmospheres, equivalent to 1
$\mathrm{MPa}$, for different short periods of times ${ }^{[34]}$. The results from this approach are shown in figure 6 where (a) is an untested disk and (b) and (c) are disks subjected to a gas pressure for times of $30 \mathrm{~s}$ and 1 minute, respectively. The formation of smooth domes in these very short forming times demonstrates conclusively the viability of using SPD processing for the production of materials that have capabilities for superplastic forming at exceptionally rapid strain rates.

Analyses have shown there is a considerable potential for achieving excellent superplastic properties in f.c.c. and h.c.p. metals through SPD processing ${ }^{[35}$ and 36]. In addition, a recent tabulation documented the many reports published to date describing superplastic flow in metallic alloys processed by ECAP, where these materials include alloys of aluminum, copper and magnesium ${ }^{[37]}$.

\section{EXAMPLES OF PROPERTIES ATTAINED THROUGH PROCESSING BY HPT}

An important advantage of HPT is that, for any selected material, the grain sizes produced by HPT processing are smaller than when using ECAP ${ }^{[38]}$. In addition, a second important difference is that HPT leads to a higher

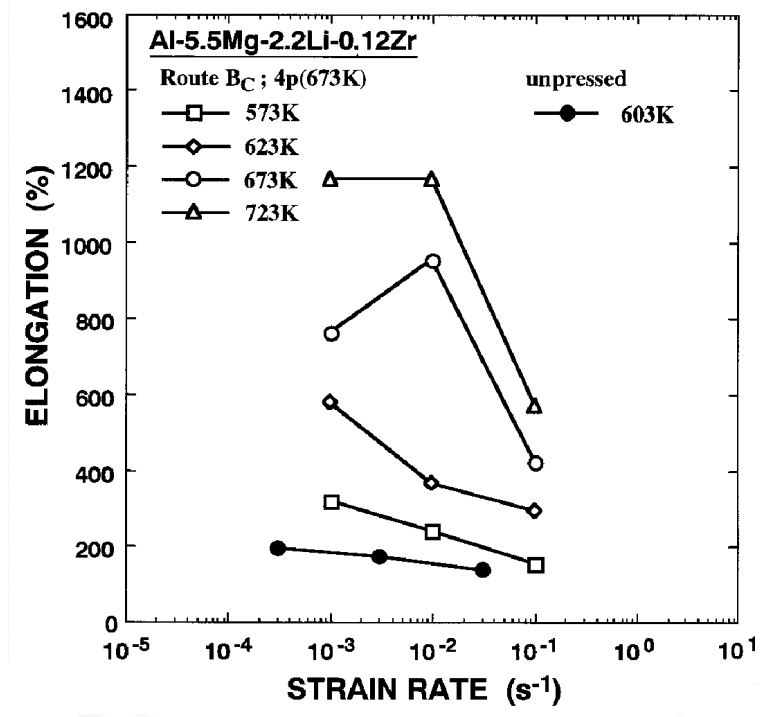

(a)

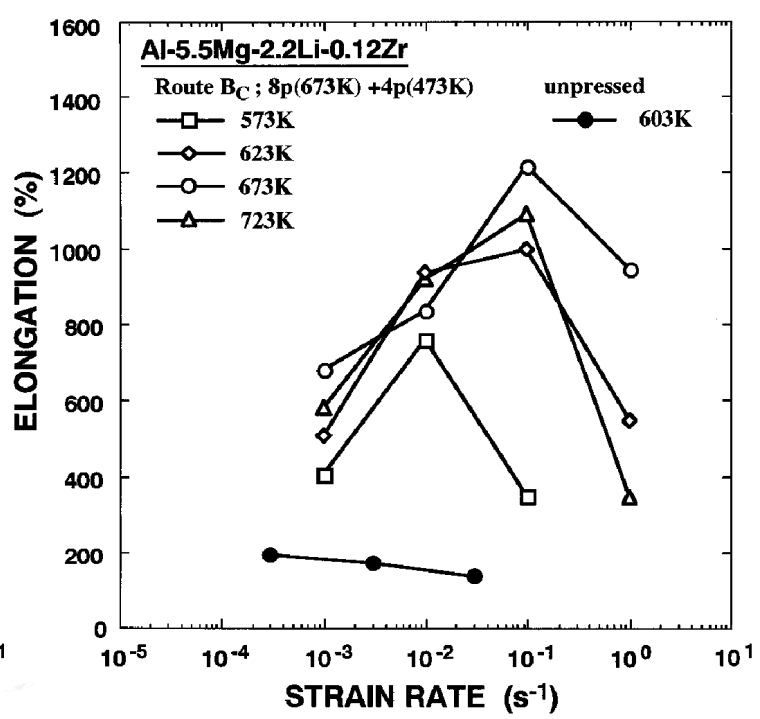

(b)

Figure 5. Elongations to failure in an Al-Mg-Li-Zr alloy after processing by ECAP (a) through 4 passes at $673 \mathrm{~K}$ and $(\mathrm{b})$ through 8 passes at $673 \mathrm{~K}$ and an additional 4 passes at $473 \mathrm{~K}$ : the lower solid points are for the unprocessed condition ${ }^{[32]}$.

Figura 5. Alargamiento a fractura en la aleación Al-Mg-Li-Zr después de procesarse por ECAP (a) a través de 4 pases a $673 \mathrm{~K}$ y (b) a través de 8 pases a $673 \mathrm{~K}$ y, adicionalmente, 4 pases a $473 \mathrm{~K}$ : los puntos sólidos inferiores son para la condición sin procesar ${ }^{[32]}$. 


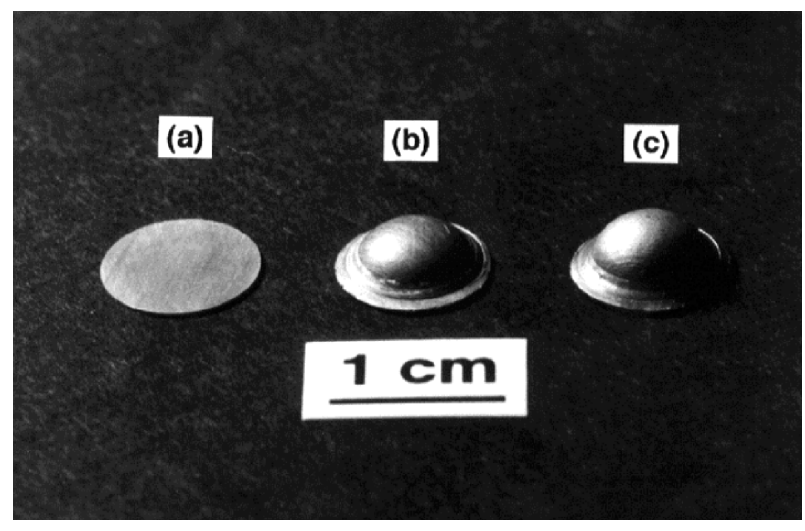

Figure 6. The rapid forming of domes in an Al$\mathrm{Mg}$-Sc alloy after processing by ECAP: (a) is an untested disk and the other disks were subjected to a gas pressure for (b) $30 \mathrm{~s}$ and (c) $1 \mathrm{~min}^{[34]}$.

Figura 6. El conformado rápidos de cúpulas en una aleación Al-Mg-Sc procesada por ECAP: a) es un disco sin ensayar y los otros discos fueron sometidos a presión de gas durante b) 30 s y c) $1 \min ^{[34]}$.

fraction of high-angle grain boundaries and therefore to a corresponding decrease in the fraction of low-angle boundaries. This is readily apparent from figure 7 which shows data for high-purity nickel after processing by (a) ECAP and (b) HPT [39]. In this investigation it was further shown that an even higher fraction of high-angle boundaries may be achieved if a sample processed by ECAP is subsequently processed by HPT.

A potential problem in HPT processing is that the strain varies across the disk and, in principle at least, it is equal to zero in the center of the disk. This suggests that materials processed by HPT may exhibit significant inhomogeneities such that they may have little or no practical use. Despite this possible trend, it was shown in very early work on high-purity $\mathrm{Ni}$ that there is a gradual evolution with increasing strain in HPT so that the microstructure tends to become reasonably homogeneous and equiaxed ${ }^{[40]}$. For nickel, hardness measurements in the early stages of HPT revealed a decrease in hardening near the center of each disc in accordance with the expectations from estimates of the imposed strains but there was also a gradual increase in the hardness in this region with subsequent straining. Similar results were reported later in an austenitic steel ${ }^{[41]}$.

The nature of this gradual evolution with increasing numbers of turns, and therefore with increasing strain, is evident in figure 8 where values of the Vickers microhardness $\mathrm{Hv}$ in an Al-6061 alloy are plotted against the position on the disk where the center of the disk lies at the central point of the plot ${ }^{[18]}$. In figure 8 the lower solid points denote the values recorded for $\mathrm{Hv}$ in the unprocessed alloy. Thus, it is apparent that there is a significant increase in hardness after 1 turn, with high values of $\mathrm{Hv}$ at the periphery of the disk but with much lower values across the central region. An increase to 5 turns displaces the points upwards throughout most of the disk but the peripheral region remains unchanged. These results suggest, therefore, that the hardness values near the edges of the disk are close to the saturation value and this saturation region gradually sweeps inwards across the disk to remove the lower values associated with the central point. This gradual change with increasing strain is consistent with a model that was developed to explain

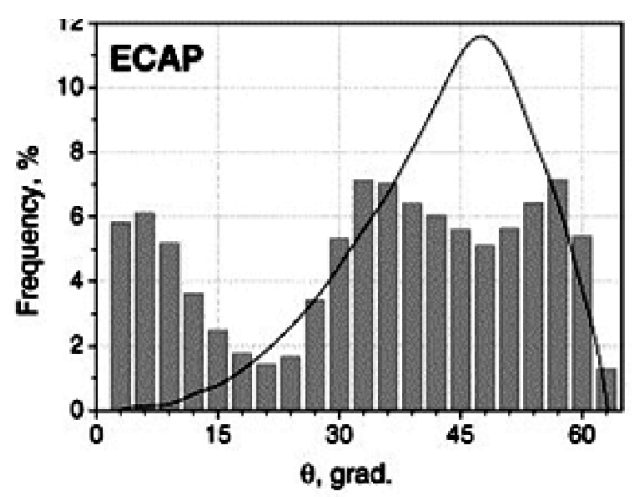

(a)

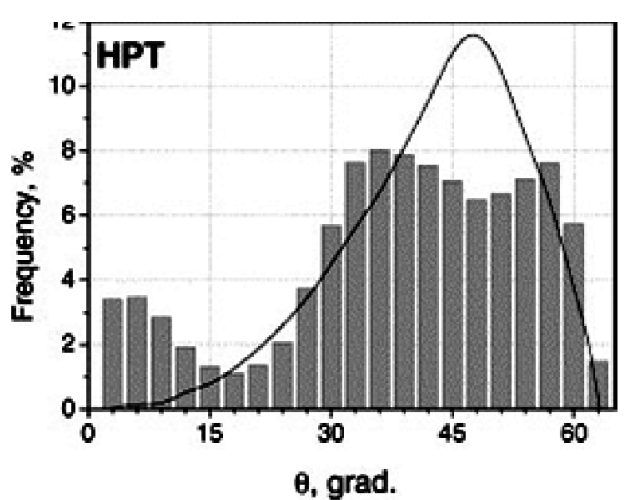

(b)

Figure 7. Grain boundary misorientation distributions in high-purity Ni after processing by (a) ECAP and (b) HPT ${ }^{[39]}$.

Figura 7. Distribución de desorientaciones de fronteras de grano en Ni de alta pureza después del procesado por a) ECAP y b) HPT[39]. 


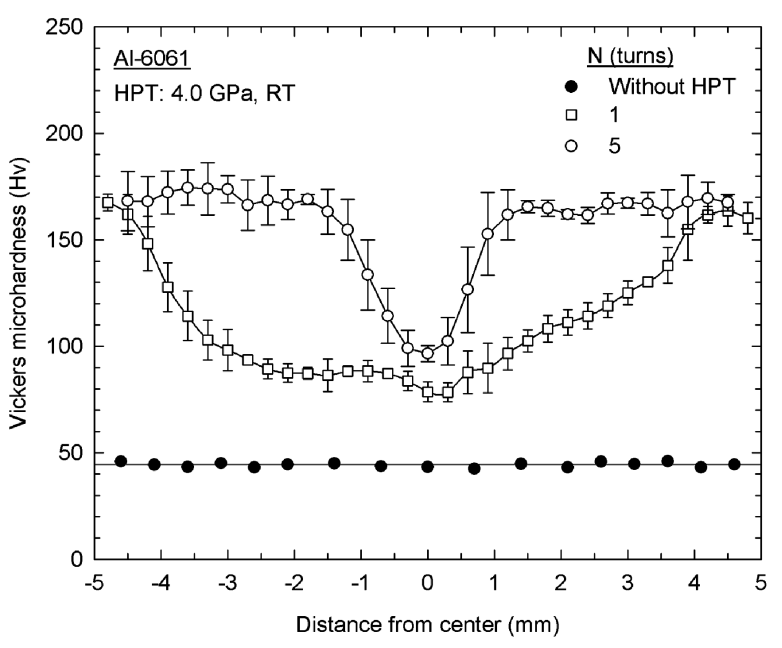

Figure 8. Average value of the Vickers microhardness, $\mathrm{Hv}$, plotted against the distance from the center of the disk after processing an Al-6061 alloy by HPT through 1 and 5 turns under an applied pressure of $4.0 \mathrm{GPa}$ : the lower solid points are for the unprocessed alloy ${ }^{[18]}$.

Figura 8. Valor medio de la microdureza Vickers, $H v$, representada frente a la distancia del centro del disco después del procesado de Al-6061 por HPT a través de 1 y 5 vueltas bajo una presión aplicada de 4.0 GPa: los puntos sólidos inferiores son para la condición sin procesar ${ }^{[18]}$.

microstructural evolution in HPT processing using strain gradient plasticity ${ }^{[42]}$.

Although the results shown in figure 8 are generally consistent with expectations because the hardness values tend to be lower in the vicinity of the central point of the disk, different results are obtained for highpurity aluminum where the values of $\mathrm{Hv}$ in the central region tend to be higher than at the periphery. An example of this effect is shown in figure 9 for a sample of high-purity $\mathrm{Al}$ processed by HPT at $1.25 \mathrm{GPa}$ at room temperature through various numbers of turns: again the solid points denote the unprocessed material ${ }^{[43]}$. Although the values of $\mathrm{Hv}$ tend to be higher close to the center, nevertheless it is apparent by close inspection that there is a gradual evolution towards a reasonable level of homogeneity across the disk after a total of 5 revolutions. The higher values of $\mathrm{Hv}$ in the central region are due to the high stacking fault energy in high-purity aluminum and the consequent rapid rate of recovery occurring around the edge of the disk.

It is important to note also that superplastic flow can be achieved after HPT processing and an example is shown in figure 10 for a bulk cylindrical sample of an

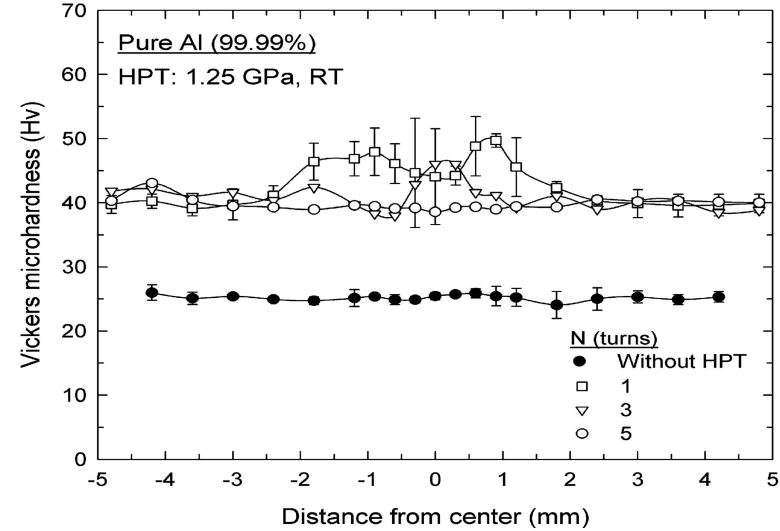

Figure 9. Average value of the Vickers microhardness, Hv, plotted against the distance from the center of the disk after processing highpurity Al by HPT through 1, 3 and 5 turns under an applied pressure of $1.25 \mathrm{GPa}$ : the lower solid points are for the unprocessed alloy ${ }^{[4]}$.

Figura 9. Valor medio de la microdureza Vickers, $\mathrm{Hv}$, representada frente la distancia del centro del disco después del procesado de Al-6061 por HPT a través de 1, 3 y 5 vueltas bajo una presión aplicada de $1.25 \mathrm{GPa}$ : los puntos sólidos inferiores son para la condición sin procesar ${ }^{[43]}$.

Al-3\% Mg-0.2\% Sc alloy torsionally strained through a total of 2 turns at room temperature ${ }^{[22]}$. By cutting a tensile specimen horizontally from the central plane of the cylinder, it was possible to achieve a tensile elongation of $1600 \%$ when pulling to fracture at 573 $\mathrm{K}$ using an initial strain rate of $3.3^{\prime} 10^{-3} \mathrm{~s}^{-1}$. The elongation recorded in figure 10 is the highest elongation reported to date for any sample prepared using HPT processing.

\section{DISCUSSION}

The results described in the previous sections demonstrate the potential for achieving exceptional properties through the use of SPD processing. Although most of the work to date has concentrated on laboratory-scale research, there is a gradual movement towards the processing of products that may have use in the commercial sector. For example, attempts are now underway to develop miniaturized ECAP facilities for the processing of materials for use in micro-electromechanical systems (MEMS) [44 and ${ }^{45]}$ and in the production of micro-gears ${ }^{[46]}$.

Recent reports have discussed the applications and innovation potential of bulk nanostructured

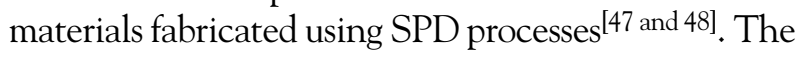




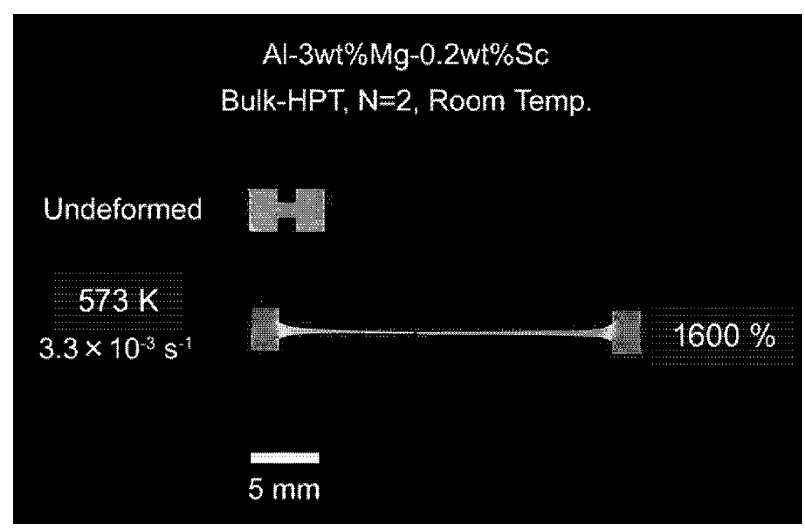

Figure 10. Exceptional superplasticity in an AlMg-Sc alloy after processing as a bulk sample by HPT ${ }^{[22]}$.

Figura 10. Superplasticidad excepcional en una aleación Al-Mg-Sc después del procesado como muestra masiva por HPT ${ }^{[22]}$.

conclusion from these analyses is that there are excellent opportunities for the use of SPD materials in operations under extreme environments or where there are special needs for unusually high strength. Examples of extreme environments include biomedical and aeronautical applications and tasks associated with cryo-arctic conditions in the oil and gas sectors.

Some specific examples are already available of the use of SPD processing in commercial ventures. For example, samples of ultrafine-grained $\mathrm{Al}$ and $\mathrm{Cu}$ processed by ECAP are now available for use as improved sputtering targets for the semiconductor industry ${ }^{[49]}$. Nanostructured implants and stints of commercial purity titanium are under active evaluation for use in various medical applications. Recently, titanium dental implants were fabricated using SPD procedures and they are undergoing clinical evaluation in a pilot program currently in progress in the European Union ${ }^{[50]}$. The biocompatibility testing of ultrafine-grained $\mathrm{Ti}^{\text {[51 and }}{ }^{52]}$ and $\mathrm{Zr}{ }^{[53]}$ has shown that the materials processed by SPD not only provide high strength but, as a consequence of the exceptionally small grain sizes, they exhibit improved compatibility in bonding with the adjacent bone structures. These results suggest, therefore, that biomedical applications will become increasingly important for these bulk nanostructured materials. Finally, it should be noted that other alternative techniques for SPD processing are also now available including twist extrusion (TE), multidirectional forging (MDF), accumulative roll-bonding (ARB) and cyclic extrusion and compression (CEC): the principles of these various procedures were described in detail in a comprehensive overview of the various SPD processing techniques ${ }^{[8]}$.

\section{SUMMARY AND CONCLUSIONS}

- Processing through the application of severe plastic deformation provides the opportunity for introducing significant grain refinement in bulk metals. Typically, the grain sizes achieved using these techniques are in the submicrometer or nanometer ranges.

- Examples are presented illustrating the processing of metals using two different techniques: equalchannel angular pressing and high-pressure torsion. Materials processed by SPD are currently receiving attention because of their use in a range of applications from sputtering targets to dental implants.

\section{Acknowledgement}

This work was supported by the U.S. Army Research Office under Grant No. W911NF-08-1-0201.

\section{REFERENCES}

[1] E.N. da C. Andrade, Nature 162 (1948) 410.

[2] N.F. Mott, Proc. Phys. Soc. London 60 (1948) 391-394.

[3] M.S. Paterson and E. Orowan, Nature 162 (1948) 991-992.

[4] W.A. Wood and W.A. Rachinger, Nature 162 (1948) 891-892.

[5] T.S. Kê, Phys. Rev. 73 (1948) 267-268.

[6] F.R.N. Nabarro, Report of a Conference on Strength of Solids, 1948, The Physical Society, London, U.K., pp. 75-90.

[7] C. Herring, J. Appl. Phys. 21 (1950) 437-445.

[8] R.Z. Valiev, Y. Estrin, Z. Horita, T.G. Langdon, M.J. Zehetbauer and Y.T. Zhu, JOM 58 (4) (2006) 33-39.

[9] J.T. Wang, Mater. Sci. Forum 503-504 (2006) 363-370.

[10] R.Z. Valiev, R.K. Islamgaliev and I.V. Alexandrov, Prog. Mater. Sci. 45 (2000) 103189.

[11] R.Z. Valiev and T.G. Langdon, Prog. Mater. Sci. 51 (2006) 881-981.

[12] A.P. Zhilyaev and T.G. Langdon, Prog. Mater. Sci. 53 (2008) 893-979. 
[13] P.B. Berbon, M. Furukawa, M. Nemoto, Z. Horita and T.G. Langdon, Metall. Mater. Trams. 30A (1999) 1989-1997.

[14] Y. Iwahashi, J. Wang, Z. Horita, M. Nemoto and T.G. Langdon, Scripta Mater. 35 (1996) 143-146.

[15] M. Furukawa, Y. Iwahashi, Z. Horita, M. Nemoto and T.G. Langdon, Mater. Sci. Eng. A257 (1998) 328-332.

[16] M. Furukawa, Z. Horita and T.G. Langdon, Mater. Sci. Eng. A332 (2002) 97-109.

[17] K. Oh-Ishi, Z. Horita, M. Furukawa, M. Nemoto and T.G. Langdon, Metall. Mater. Trans. 29A (1998) 2011-2013.

[18] C. Xu, Z. Horita and T.G. Langdon, Acta Mater. (2008) in press.

[19] Z. Horita, T. Fujinami and T.G. Langdon, Mater. Sci. Eng. A318 (2001) 34-41.

[20] R. Srinivasan, B. Cherukuri and P.K. Chaudhury, Mater. Sci. Forum 503-504 (2006) 371-378.

[21] G. Sakai, K. Nakamura, Z. Horita and T.G. Langdon, Mater. Sci. Eng. A406 (2005) 268273.

[22] Z. Horita and T.G. Langdon, Scripta Mater. 58 (2008) 1029-1032.

[23] M. Kawasaki and T.G. Langdon, Mater. Sci. Eng. (2008) in press.

[24] Y. Iwahashi, Z. Horita, M. Nemoto and T.G. Langdon, Metall. Mater. Trans. 29A (1998) 2503-2510.

[25] T.G. Langdon, Mater. Sci. Eng. A462 (2007) 3-11.

[26] E.O. Hall, Proc. Roy. Soc. B 64 (1951) 747 753.

[27] N.J. Petch, J. Iron Steel Inst. 174 (1953) 25-28.

[28] Z. Horita, T. Fujinami, M. Nemoto and T.G. Langdon, Metall. Mater. Trans. 31A (2000) 691-701.

[29] T.G. Langdon, Acta Metall. Mater. 42 (1994) 2437-2443.

[30] Y. Ma, M. Furukawa, Z. Horita, M. Nemoto, R.Z. Valiev and T.G. Langdon, Mater. Trans. JIM 37 (1996) 336-339.

[31] R.Z. Valiev, D.A. Salimonenko, N.K. Tsenev, P.B. Berbon and T.G. Langdon, Scripta Mater. 37 (1997) 1945-1950.

[32] S. Lee, P.B. Berbon, M. Furukawa, Z. Horita, M. Nemoto, N.K. Tsenev, R.Z. Valiev and T.G. Langdon, Mater. Sci. Eng. A272 (1999) 63-72.

[33] A.J. Barnes, J. Mater. Eng. Perform. 16 (2007) 440-454

[34] Z. Horita, M. Furukawa, M. Nemoto, A.J. Barnes and T.G. Langdon, Acta Mater. 48 (2000) 3633-3640.
[35] M. Kawasaki, R.B. Figueiredo, C. Xu and T.G. Langdon, Metall. Mater. Trans. 38A (2007) 1891-1898.

[36] R.B. Figueiredo, M. Kawasaki, C. Xu and T.G. Langdon, Mater. Sci. Eng. A493 (2008) 104-110.

[37] M. Kawasaki and T.G. Langdon, J. Mater. Sci. 42 (2007) 1782-1796.

[38] A.P. Zhilyaev, B.K. Kim, G.V. Nurislamova, M.D. Baró, J.A. Szpunar and T.G. Langdon, Scripta Mater. 48 (2002) 575-580.

[39] A.P. Zhilyaev, B.K. Kim, J.A. Szpunar, M.D. Baró and T.G. Langdon, Mater. Sci. Eng. A391 (2005) 377-389.

[40] A.P. Zhilyaev, G.V. Nurislamova, B.K. Kim, M.D. Baró, J.A. Szpunar and T.G. Langdon, Acta Mater. 51 (2003) 753-765.

[41] A. Vorhauer and R. Pippan, Scripta Mater. 51 (2004) 921-925.

[42] Y. Estrin, A. Molotnikov, C.H.J. Davies and R. Lapovok, J. Mech. Phys. Solids 56 (2008) 11861202.

[43] C. Xu, Z. Horita and T.G. Langdon, Acta Mater. 55 (2007) 203-212.

[44] A. Zi, Y.Estrin, R.J. Hellmig, M. Kazakevich and E. Rabkin, Solid State Phenom. 114 (2006) 265-269.

[45] Y. Estrin, M. Janecek, G.I. Raab, R.Z. Valiev and A. Zi, Metall. Mater. Trans. 38A (2007) 1906-1909.

[46] W.J. Kim and Y.K. Sa, Scripta Mater. 54 (2006) 1391-1395.

[47] Y.T. Zhu, T.C. Lowe and T.G. Langdon, Scripta Mater. 51 (2004) 825-830.

[48] R.Z. Valiev, M.J. Zehetbauer, Y. Estrin, H.W. Höppel, Y. Ivanisenko, H. Hahn, G. Wilde, H.J. Roven, X. Sauvage and T.G. Langdon, Adv. Eng. Mater. 9 (2007) 527-533.

[49] S. Ferrasse, V.M. Segal, F. Alford, J. Kardokus and S. Strothers, Mater. Sci. Eng. A493 (2008) 130-140.

[50] R.Z. Valiev, I.P. Semenova, V.V. Latysh, H. Rack, T.C. Lowe, J. Petruzelka, L. Dluhos, D. Hrusak and J. Sochova, Adv. Eng. Mater. 10 (2008) B15-B17.

[51] S. Faghihi, A.P. Zhilyaev, J.A. Szpunar, F. Azari, H. Vari and M. Tabrizian, Adv. Mater. 19 (2007) 1069-1073.

[52] S. Faghihi, F. Azari, A.P. Zhilyaev, J.A. Szpunar, H. Vali and M. Tabrizian, Biomater. 28 (2007) 3887-3895.

[53] L. Saldaña, A. Méndez-Vilas, L. Jiang, M. Multigner, J.L. González-Carrasco, M.T. PérezPrado, M.L. González-Martín. L. Munvera and N. Vilaboa, Biomater. 28 (2007) 4343-4354. 